\title{
Direct and indirect effects of the introduced alga Sargassum muticum on benthic, subtidal communities of Washington State, USA
}

\author{
Kevin H. Britton-Simmons ${ }^{1, *}$ \\ Department of Ecology and Evolution, The University of Chicago, 1101 East 57th Street, Chicago, Illinois 60637, USA \\ ${ }^{1}$ Present address: University of Washington, Friday Harbor Laboratories, 620 University Road, Friday Harbor, \\ Washington 98250, USA
}

\begin{abstract}
Introduced algae have become a prominent component of the marine flora in many regions worldwide. In the NE Pacific, the introduced Japanese alga Sargassum muticum (Yendo) Fensholt is common and abundant in shallow, subtidal, rocky habitats, but its effects on subtidal, benthic communities in this region have not previously been studied. I measured the response of native species to experimental manipulation of $S$. muticum in field experiments in the San Juan Islands of Washington State. Native canopy (brown) and understory (red) algae were more abundant in plots from which $S$. muticum had been removed, and the native kelp Laminaria bongardiana (the most abundant species of brown alga in the absence of $S$. muticum) grew more than twice as fast in plots where $S$. muticum was absent. The negative effects of $S$. muticum on native algae appear to be a result of shading, rather than changes in water flow, sedimentation, or nutrient availability. S. muticum also had a strongly negative indirect effect on the native sea urchin Stronglyocentrotus droebachiensis by reducing abundances of the native kelp species on which it prefers to feed. My results indicate that $S$. muticum has a substantial impact on native communities in this region, including effects at multiple trophic levels. Because of their worldwide distribution and capacity to alter native communities, non-indigenous algae are potentially important agents of global ecological change.
\end{abstract}

KEY WORDS: Sargassum muticum · Introduced algae $\cdot$ Competition · Indirect effects $\cdot$ Stronglylocentrotus droebachiensis · Shading

Resale or republication not permitted without written consent of the publisher

\section{INTRODUCTION}

Introduced algae have become a prominent component of the marine flora in many regions worldwide (Rueness 1989, Verlaque 1994a, DeWreede 1996, Cohen et al. 2001). Despite their widespread distribution, few studies have rigorously documented the effects of exotic algae and as a consequence many of their possible impacts remain speculative. Nevertheless, available evidence suggests that introduced algae do have the potential to substantially alter native communities (Verlaque 1994b, Villele \& Verlaque 1995, Walker \& Kendrick 1998, Levin et al. 2002). In the present study, I experimentally evaluate the impact of the introduced Japanese alga Sargassum muticum
(Yendo) Fensholt, on native, subtidal kelp communities in Washington State, USA.

Sargassum muticum is native to SE Asia (Yendo 1907), but its present distribution as an invasive species is widespread, including Europe, the Mediterranean Sea and the west coast of North America. In the United States, S. muticum was introduced to Washington State in the early 20th century, probably with shipments of Japanese oysters that were imported for aquaculture beginning in 1902 (Scagel 1956). Following its establishment in this region, it subsequently invaded over $3000 \mathrm{~km}$ of coastline on the west coast of North America (Scagel 1956, Setzer \& Link 1971). S. muticum has now become established in low intertidal and shallow subtidal habitats throughout Puget Sound 
and the San Juan Islands (own pers. obs.), where it occurs in densities as high as 126 plants $\mathrm{m}^{-2}$ (own unpubl. data).

In areas where Sargassum muticum is abundant in the San Juan Islands, it forms a dense covering that towers up to $2 \mathrm{~m}$ above all but 1 native algal species, Nereocystis luetkeana. These dense stands of $S$. muticum may reduce light, dampen flow, increase sedimentation and reduce ambient nutrient concentrations available for native kelp species (order Laminariales). Because kelps are an important source of carbon in coastal food webs (Duggins et al. 1989) and the algal communities they are associated with provide habitat and food for a wide variety of marine animals (Jones 1971, Bernstein \& Jung 1979, Ebeling et al. 1985), any negative effects of $S$. muticum on these communities may have broader consequences for this ecosystem.

Previous studies have varied substantially in their conclusions about how strong an effect Sargassum muticum has on native communities. While intertidal studies in British Columbia (DeWreede 1983) and Spain (Viejo 1997) suggest that it competes with native algae, a study in California tidepools found no effect (Wilson 2001). Subtidal studies have found evidence for inhibition of giant kelp recruitment in California (Ambrose \& Nelson 1982) and for competition with native algae in Denmark (Staehr et al. 2000). Interestingly, in the San Juan Islands, $S$. muticum supports a more abundant and species-rich epibiont community than the native kelp Laminaria saccharina (Giver 1999), which it is thought to displace. Previous studies have focused almost exclusively on competitive interactions of $S$. muticum with other algae and have not investigated its potential influence on other trophic levels (but see Wilson 2001).

The goal of this study was to investigate the effect of Sargassum muticum on native kelp communities in the San Juan Islands of Washington State by measuring the response of native algae and invertebrates to experimental manipulation of the presence of $S$. muticum. I was also interested in the mechanism(s) underlying the effects of $S$. muticum. By measuring light, nutrients, water flow and sedimentation in experimental plots in the field, I tested several hypotheses about how $S$. muticum changed the abiotic environment. I predicted that $S$. muticum should decrease light, water flow and nutrients, but that it should increase sedimentation.

\section{MATERIALS AND METHODS}

Study sites. This research was based at Friday Harbor Laboratories (hereafter FHL) on San Juan Island, Washington State, USA. Field work was accomplished using SCUBA. Removal experiments and associated kelp growth experiments were carried out at 2 sites within the San Juan Islands Marine Preserve network adjacent to San Juan and Shaw Islands, known locally as Colin's Cove $\left(48^{\circ} 33.16^{\prime} \mathrm{N}, 122^{\circ} 58.79^{\prime} \mathrm{W}\right)$ and Point George $\left(48^{\circ} 32.97^{\prime} \mathrm{N}, 123^{\circ} 00.33^{\prime} \mathrm{W}\right)$, respectively. These reserves were established in 1990 and are closed to harvesting with very limited exceptions (e.g. salmon). Laboratory experiments were completed at FHL.

The 2 field sites vary in their physical characteristics. The habitat at Colin's Cove is composed primarily of relatively flat, rocky reefs with some small boulders. In contrast, the substratum at Point George is more heterogeneous, with rocky reef overlaid by a layer of small to medium-sized boulders. Point George is also subjected to more intense tidal currents than Colin's Cove.

Despite these differences in abiotic habitat, both field sites are similar in the biological community they support. The native kelp communities that dominate shallow, subtidal habitats in this region are speciesrich and structurally complex. The upper layer of the algal community is composed of a canopy of large, brown algae in the orders Laminariales and Desmarestiales, referred to herein as canopy algae. The middle layer consists of an assemblage of fleshy red algae from a variety of orders, referred to herein as understory algae. The bottom layer is formed by encrusting coralline algae and filamentous, turf-forming algae. Herbivores in this shallow subtidal system include the green sea urchin Strongylocentrotus droebachiensis and a variety of grazing molluscs including chitons, limpets and snails.

Background information on Sargassum muticum. $S$. muticum is a brown alga in the order Fucales. Although the plant is a perennial, its lateral branches are only present for a portion of the year. The phenology of $S$. muticum's life cycle varies regionally. In the San Juan Islands, its numerous lateral branches begin growing in early March, reach their maximum height in June, and begin to senesce in mid- to late-August. Only the short ( 5 to $10 \mathrm{~cm}$ ) basal holdfast portion overwinters in a quiescent state. In the San Juan Islands, each holdfast produces as many as 18 laterals in the early spring, each of which can grow as tall as $3 \mathrm{~m}$. Small pneumatocysts along the primary axis of each lateral make it positively buoyant and cause the laterals to extend vertically into the water column. $S$. muticum has a simple life cycle. Reproductive structures called receptacles are borne along secondary branches and contain both oogonia and antheridia. After eggs are released from the oogonia, they adhere to the external surface of the receptacle, where they are fertilized. Fertilized embryos remain attached to the receptacle until they develop tiny, adhesive rhizoids, at which point they detach and recruit to the 
substratum in close proximity to the parent plant (Deysher \& Norton 1982).

Sargassum muticum removal experiments. I designed experiments to test the hypothesis that the presence of $S$. muticum was influencing the structure of the native community. During June 1999, 2 removal experiments were simultaneously initiated at Point George and Colin's Cove. At each site, ten $50 \times 50 \mathrm{~cm}$ plots, at a depth of $-2 \mathrm{~m}$ mean lower low water (MLLW) and containing high densities of $S$. muticum, were permanently marked using metal-stamped stainless steel washers and marine epoxy (Z-Spar splash zone compound $\left.{ }^{\mathrm{TM}}\right)$. At each site, the experimental plots were arranged in a line parallel to shore; the average distance between plots was $2.5 \mathrm{~m}$. Plots were then randomly assigned to control or removal treatments. Control plots were not altered. Removal plots had all $S$. muticum plants eliminated, both from within the plots and from a $50 \mathrm{~cm}$ buffer surrounding the plots. Each $S$. muticum plant was removed by carefully prying its small (1 to $2 \mathrm{~cm}$ in diameter), discoid holdfast off the rock substrate with a small dive knife. The buffer zone was created in order to reduce shading or other effects of adjacent $S$. muticum plants. The initial $S$. muticum removal began on June 30, 1999 and was completed at both sites by July 5, 1999. The removal treatment was maintained over the course of the experiment by removing any new $S$. muticum recruits from removal plots and adjacent buffer zones several times per year.

All experimental plots were censused once prior to imposing the removal treatment and then 2 to 6 times per year thereafter. At the time of each census, I recorded the identity and number of all macroalgae in each experimental plot. In addition, I estimated the percentage of primary space on the rock substrate that was covered by crustose algae, filamentous algae, fleshy red algae, fleshy brown algae, Sargassum muticum and bare rock. The percent cover estimates were carried out on a $25 \times 25 \mathrm{~cm}$ subplot. Benthic invertebrates were counted in the baseline and first postremoval census and then twice per year thereafter. Time and weather constraints prevented complete censuses of all taxa of interest on some sampling dates.

Light measurements. I measured light levels in all removal experiment plots on 4 dates in 2000 (March 21, May 12, June 9 and August 22). Sargassum muticum's fronds are present for only part of the year (typically March to August), and therefore any effect they have on light should be limited to this time period. Because my sampling dates spanned the months of March to August, and included dates when the fronds were absent and present, I was able to use these data to test the hypothesis that $S$. muticum reduced ambient light levels in plots where it was present. Measurements of photosynthetically active radiation (400 to $700 \mathrm{~nm}$ ) were taken simultaneously at surface and at depth using a Licor LI-1000 data logger coupled to 2 quantum sensors. Surface measurements were taken from a small boat, and measurements at depth were taken $30 \mathrm{~cm}$ above the substratum in the center of each control and removal treatment plot. Because Nereocystis luetkeana, the only native algae species that is taller than $S$. muticum, was not present in any of my plots at the time and because the remaining kelp species have demersal blades that typically extend less than $30 \mathrm{~cm}$ above the substratum, measuring light at $30 \mathrm{~cm}$ allowed me to isolate the effect of $S$. muticum. Light was measured at $1 \mathrm{~s}$ intervals for $1 \mathrm{~min}$ in each plot. Plots were sampled systematically, beginning at one end of the site and proceeding to the other end in quick succession, in order to minimize the time elapsed between samples. The same sampling protocol was used on all sampling dates. Light measurements were always taken at both sites on the same day and the sampling period straddled noon. Whenever possible, samples were taken on a cloudless day. The average of the 60 instantaneous measurements at the surface and at depth was used to calculate percent transmittance (light at depth/light at surface), which is the quantity reported and used in statistical analyses.

Water flow measurements. Because Sargassum muticum's fronds form dense stands extending several meters into the water column, they have the potential to dampen water flow. I tested the hypothesis that $S$. muticum reduced water flow, using alabaster dissolution blocks following the methods of Eckman et al. (1989). Small blocks of alabaster (di-hydrated calcium sulfate) were cut from a larger block and sanded to uniform dimensions (average of $46 \times 42 \times 10 \mathrm{~mm}$ ). Blocks (1 per plot) were anchored to threaded steel rods at a height of $30 \mathrm{~cm}$ above the substratum, which is above all kelp species present (Nereocystis luetkeana was not in any experimental plot at this time) but below $S$. muticum, thereby isolating the effect of $S$. muticum on flow. The threaded steel rods were screwed into tubes of hexagonal nuts (8 nuts stacked on top of one another so that the threaded holes lined up) that had been attached to the rock substratum with marine epoxy (Z-Spar splash zone compound ${ }^{\mathrm{TM}}$ ). In order to prevent abrasion by seaweed, blocks were enclosed in hardware cloth cages (mesh squares = $12 \mathrm{~mm}$ on a side), which were also attached to the threaded steel rods by stainless steel hardware. Before and after deployment, the blocks were dried to a constant weight at $60^{\circ} \mathrm{C}$ and weighed to the nearest $1 \mathrm{mg}$. The blocks were deployed on August 27, 1999 and collected on August 29, 1999 for a total deployment time of $42.5 \mathrm{~h}$.

Sedimentation measurements. Any effect that Sargassum muticum has on water flow is likely to influ- 
ence the flux of particulate matter from the water column to the substrate. I measured sedimentation rates in each removal experiment plot during July 2001 in order to test the hypothesis that $S$. muticum increases sedimentation rates. Many native algae (including kelps) are recruiting during this time and increased sedimentation rates could have important effects on community development by altering patterns of algal settlement or survivorship. Although nearly all sediment traps have drawbacks and no trap design has been developed specifically for shallow, subtidal habitats, I chose a design that was recommended for use in strong currents like those characteristic of my system (Gardner 1980, Jeurg 1996). Specifically, a cylinder with a height-to-diameter ratio of at least 4.5 and a minimum diameter of $3.9 \mathrm{~cm}$ is recommended for strong currents to prevent resuspension of sediments that have already been trapped (Gardner 1980). I constructed cylindrical traps from PVC that were $32 \mathrm{~cm}$ in height and $6 \mathrm{~cm}$ in diameter. The traps were attached to the rock substrate just adjacent to each plot by screwing a bolt that protruded from the bottom of each trap into a tube of hexagonal nuts that had been attached to the rock with marine epoxy (Z-Spar splash zone compound ${ }^{\mathrm{TM}}$ ). Traps were deployed for a single $10 \mathrm{~d}$ sampling period, which spanned portions of both a spring (when sedimentation should be lowest) and a neap (when sedimentation should be the highest) tide series, and therefore should give an indication of the average effect of $S$. muticum on sedimentation. Prior to removal, each trap was capped with a PVC lid to prevent loss of contents during transport to FHL for processing. All samples were immediately frozen at $-70^{\circ} \mathrm{C}$ until they could be processed.

After removing large animals (e.g. hermit crabs) and pieces of algae with a coarse ( $4 \mathrm{~mm})$ mesh, I used a vacuum pump to filter the sediment onto glass microfiber filters that had been baked in a muffle furnace at $500^{\circ} \mathrm{C}$ (to remove any organic content) for $6 \mathrm{~h}$. The sedimentladen filters were then dried to a constant weight at $60^{\circ} \mathrm{C}$, weighed (to the nearest $\mathrm{mg}$ ), baked for $6 \mathrm{~h}$ in a $300^{\circ} \mathrm{C}$ muffle furnace (to burn off organic content) and weighed again. This protocol allowed me to separate out organic and inorganic components of the sediment.

Nutrient measurements. Dense stands of Sargassum muticum have the potential to reduce ambient levels of critical nutrients to levels that might negatively affect the growth of native algae. In August 1999, I took a single water sample from the center of each experimental plot to test the hypothesis that $S$. muticum reduced ambient nutrient concentrations in plots where it was present. All samples were taken at slack current when water movement is at a minimum, and any dilution effect of $S$. muticum on the local nutrient pool would be most likely to be detected. Because the length of time necessary to complete the collection and processing of samples for both sites exceeded the slack current period, the 2 sites were sampled on successive days. Point George water samples were taken on August 5, 1999 and Colin's Cove water samples were taken on August 6, 1999.

Nalgene bottles (1 l) were acid-washed in a $10 \% \mathrm{HCl}$ solution and dried. Each plot was sampled by placing a bottle in the center of the plot, removing the lid and allowing it to fill. Capped bottles were brought to the surface and immediately placed in an ice-filled cooler until being processed in the boat. A subsample of the water in each bottle was extracted with a syringe and filtered through a glass microfiber filter into a smaller bottle which was placed in an ice-filled cooler. The remaining water in the 11 bottles was then discarded. Larger bottles were used for collecting the water samples underwater in order to facilitate the extraction of the water to be analyzed once they were brought to the surface. Samples were immediately transported to the laboratory where they were frozen (and stored) at $-70^{\circ} \mathrm{C}$ until being shipped to the University of Washington's School of Oceanography, where they were processed using standard protocols (UNESCO 1994) for determination of ammonium, nitrate, nitrite, phosphorus, and silica concentrations.

Kelp growth experiment. I used a kelp growth experiment at 2 sites in July 2000 to test the hypothesis that Sargassum muticum negatively affects kelp growth. I used the native kelp Laminaria bongardiana (formerly L. groenlandica), which was the most common kelp at the 2 removal experiment sites, as the focal species. L. bongardiana plants that were similar in size $(8.1 \pm 2.6 \mathrm{~g}=$ mean $\pm 1 \mathrm{SD})$ were collected intact from the field and brought to the laboratory where they were kept in flow-through seawater tanks until their return to the field less than $24 \mathrm{~h}$ later. Transplanting was accomplished as follows. A cinder block $(39.5 \times 14.5 \times 19 \mathrm{~cm})$ with eye bolts inserted at each end was placed in the area just adjacent to each experimental plot from which $S$. muticum had been removed (removal) or left intact (control). A single length of braided nylon rope, containing 3 L. bongardiana whose holdfasts had been woven into it, was then attached to each cinder block by tying the ends of the rope to the eye bolts. The cinder block served to elevate transplanted kelps above the substratum slightly, reducing shading by adjacent kelps and thereby better isolating the effect of $S$. muticum. Each plant was individually marked with a piece of numbered flagging tape tied gently around the stipe. Plants were spaced at $10 \mathrm{~cm}$ intervals on the ropes and were randomly assigned to sites and treatments.

I used 3 metrics to quantify growth during the $28 \mathrm{~d}$ experiment: (1) change in mass was determined by 
weighing kelps to the nearest $0.1 \mathrm{~g}$ before and after transplanting them to the field; prior to weighing, each plant was held aloft and shaken vigorously and then patted dry with paper towels to remove excess water. (2) Change in blade area was measured by tracing the blade area of each plant onto butcher paper before and after transplanting them to the field; blade traces were converted to area by cutting them out, weighing them and converting those weights to area using a conversion factor determined by weighing pieces of butcher paper of known area. (3) Linear blade growth was measured by using a cork borer to remove a circular piece of blade tissue $2 \mathrm{~cm}$ in diameter at the midpoint of the blade, $4 \mathrm{~cm}$ from the meristem region and measuring the distance the hole moved distally during the experiment.

Urchin food-preference experiment. Data collected in the removal experiment showed that green urchins avoided foraging in control plots, where Sargassum muticum was present. I compared the feeding of Strongylocentrotus droebachiensis on $S$. muticum relative to the native kelps Agarum fimbriatum and Laminaria bongardiana, to test the hypothesis that the urchin's distaste for $S$. muticum caused it to avoid S. muticumdominated plots. These 2 native kelps were the numerically dominant canopy species in removal plots at both experimental sites, but they differ considerably in terms of palatability to urchins. Whereas $L$. bongardiana is a preferred food of green urchins in this region, A. fimbriatum is consistently avoided in food preference experiments (Vadas 1977). This difference in preference probably reflects the 5 to 10 times higher levels of polyphenolics (chemicals known to deter herbivory) in A. fimbriatum than in $L$. bongardiana (Hammerstrom et al. 1998). By scaling the green urchin's feeding rate on $S$. muticum against 2 native kelp species whose relative palatability was already known, I hoped to better characterize its response to S. muticum as a potential food source.

I had 2 hypotheses about why urchins may not feed on Sargassum muticum in the field: (1) they find its tissue unpalatable, or (2) its positively buoyant fronds make it inaccessible to urchins. I designed this feeding experiment to test Hypothesis 1 and controlled the accessibility of the 3 algae species in this experiment to ensure that all 3 species were equally available for urchins to feed on.

The experiment was carried out in 7 circular outdoor aquaria (105 $\mathrm{cm}$ in diameter, $45 \mathrm{~cm}$ tall). All aquaria had a constant supply of unfiltered seawater from the FHL seawater system throughout the experiment. Each aquarium was divided in half with plastic Vexar mesh (oval holes measuring $2.6 \times 1.9 \mathrm{~cm}$ ); this allowed water to flow freely throughout the tank while isolating urchins on 1 side. Each side of each aquarium con- tained a single specimen of each of the 3 algal species that had been collected from the field on the day the experiment was set up. Plants were attached to the bottom in random order by inserting holdfasts into small incisions that were positioned $10 \mathrm{~cm}$ apart in a Rubbermaid ${ }^{\mathrm{TM}}$ bathmat adhering tightly to the bottom. In addition to being attached at the holdfast, each Sargassum muticum plant was bent over and cable-tied to the bathmat at a point approximately $30 \mathrm{~cm}$ away from the holdfast. This ensured that all species of algae were equally accessible and experimental results reflected actual food preferences, unconfounded by the urchin's inability to access and feed on S. muticum.

Urchins were collected from the field on the morning the experiment was set up (May 1, 2001) and kept in a flow-through seawater tank until being placed in experimental tanks. The 2 sides of each tank were randomly assigned to either urchin or control treatments and 6 urchins ( 6 to $10 \mathrm{~cm}$ in diameter) were placed in each half-tank assigned to the urchin treatment. Urchins were assigned to tanks such that each tank had a range of sizes and total urchin mass per tank was approximately equal. The density of urchins used in this experiment $\left(3.5\right.$ urchins $\left.\mathrm{m}^{-2}\right)$ is within the range of natural densities I have recorded in the field. Consumption of each algae species over the $3 \mathrm{~d}$ experiment was calculated by pairing control and urchin treatments from each tank and applying the formula $\left[T_{\mathrm{i}}\left(C_{\mathrm{f}} / C_{\mathrm{i}}\right)\right]-T_{\mathrm{f}}$, where $T_{\mathrm{i}}$ and $T_{\mathrm{f}}$ are the initial and final algae masses in treatment tanks and $C_{\mathrm{i}}$ and $C_{\mathrm{f}}$ are the initial and final algae masses in the randomly paired control tank (Peterson \& Renaud 1989). Prior to weighing algae at the beginning and end of the experiment, each individual was held aloft and shaken gently to remove excess water from its surface, and then spun in a salad spinner for $20 \mathrm{~s}$.

Urchin predation experiment. Increased predation by sea stars in Sargassum muticum-dominated areas is an alternative hypothesis that could also explain the near-absence of green urchins in the control plots in the removal experiment at Point George. Algal canopies dominated by $S$. muticum might enable the sea star Pycnopodia helianthoides (a locally common predator on green urchins) to prey more effectively on green urchins. Green urchins typically cover their aboral surface with kelp or other algae while feeding, but $S$. muticum's positively buoyant fronds and wiry morphology make it unsuitable for this purpose. Therefore, green urchins might be more vulnerable to predation by $P$. helianthoides in areas where $S$. muticum is the dominant alga because they may be unable to effectively hide themselves.

I used a laboratory experiment in seawater tanks at FHL in May 2003 to test whether predation on urchins by sea stars differed in a Sargassum muticum mono- 
culture versus a mixed kelp canopy. I divided 7 outdoor aquaria $(105 \mathrm{~cm}$ in diameter, $45 \mathrm{~cm}$ tall) in half using plastic Vexar mesh (oval holes measuring $2.6 \times$ $1.9 \mathrm{~cm})$. This setup allowed water to flow freely throughout the tank while preventing urchins from moving between the 2 sides of the tanks. All aquaria had a constant supply of unfiltered seawater from the FHL seawater system throughout the experiment. The halves of each tank were randomly assigned to 1 of 2 experimental treatments: (1) S. muticum monoculture, or (2) mixed canopy of Laminaria bongardiana and Agarum fimbriatum; so that each tank contained 1 replicate of each treatment. The densities of $S$. muticum $\left(29 \mathrm{~m}^{-2}\right)$ and kelps $\left(25 \mathrm{~m}^{-2}\right)$ used in the experiment were determined from the average densities of these species in the field. The algae used in the experiment were collected on the day preceding and the day of beginning the experiment, and were attached to the bottom of the tanks by inserting their holdfasts into small incisions in Rubbermaid ${ }^{\mathrm{TM}}$ bathmats adhered tightly to the bottom of the tanks. I used a mixture of sizes for each species in order to mimic the size structure typical of algae populations in the field ( $S$. muticum: 30 to $60 \mathrm{~cm}$ tall; A. fimbriatum and L. bongardiana: 25 to $60 \mathrm{~cm}$ tall). The order of species (in the kelp treatment) and their spatial arrangement on the mats was haphazard.

Once the algal treatments were set up, I placed 8 Strongylocentrotus droebachiensis on each side of each tank. All urchins were dropped into the tanks around the perimeter and were allowed to acclimate for $18 \mathrm{~h}$ before the sea stars were added. The urchins were collected over a 1 mo long period preceding the experiment and were kept in flow-through seawater tanks and fed a mixed algal diet prior to their use in the experiment. I divided the urchins into 2 size classes ( 50 to $65 \mathrm{~mm}$, and 65 to $80 \mathrm{~mm}$ ) and randomly selected 4 urchins from each for each experimental unit. The sea stars Pycnopodia helianthoides $(40$ to $60 \mathrm{~cm}$ in diameter) used in the experiment were collected on the day preceding and the day of beginning the experiment, and were kept in flow-through seawater tanks without food until being placed in the experimental tanks. In order to ensure that the variation in sea star size was evenly distributed across the treatments, I paired sea stars of equal size and randomly assigned them to opposite sides of the same tank until each tank had 1 sea star per side. The tanks were lightly shaded using a double layer of thick, cotton fishing net $\left(4 \mathrm{~cm}^{2}\right.$ mesh size) in order to mimic the shallow subtidal light conditions where these species normally interact. Additional light reduction was achieved by wrapping the south-facing half of each tank in a layer of black plastic. This experiment was allowed to run for a total of $8 \mathrm{~d}$. On Days 3 and 8 of the experiment I recorded the number of urchins that were visible from above in each tank. These individuals should be more vulnerable to predation by visual predators (e.g. crabs) and tactile predators (e.g. sea stars). At the end of the experiment all sea stars were removed from the tanks and the remaining urchins were counted.

Statistical analyses. Most statistical analyses were carried out using SYSTAT version 9.0 (SPSS). Because many native species were not present in all removal experiment plots, and because I expected functionally similar species to respond similarly to the presence of Sargassum muticum, I grouped native species into functional groups in addition to carrying out singlespecies analyses for the most common native species. Macroalgae were separated into 2 groups: (1) understory-small, red species (e.g. Rhodoptilum plumosum, Odonthalia spp., Plocamium cartilagineum, Gigartina papillata, Laurencia spectabilis, Opuntiella californica and Callophyllis spp.), and (2) canopylarge, brown species (Laminaria bongardiana, L. complenata, Agarum cribrosum, A. fimbriatum, Costaria costata, Nereocystis luetkeana, Alaria marginata, Desmarestia ligulata and $D$. viridis). Native invertebrates were separated into 2 main groups: (1) herbivorous molluscs (Mopalia spp., Cryptochiton stelleri, Tonicella lineata, Acmea mitra, Diodora aspera, Margarites pupillus and Lacuna vincta), and (2) detritivores (Bittium eschrichtii, Pandalus spp., and Pagurus spp.). The data for Strongylocentrotus droebachiensis were analyzed independently from those for other herbivores. Because the single-species analyses did not yield any new insights (with the exception of $S$. droebachiensis), the data presented in this paper are generally for the functional groupings.

Biological data from the removal experiments were analyzed using repeated-measures ANOVA, blocking by site. Site (2 levels, Point George and Colin's Cove) and Treatment (2 levels, control and removal) were both treated as fixed factors. For each response variable, I first performed a 2-way ANOVA on the pre-removal census data to test the hypothesis that control and removal plots differed prior to imposing the removal treatment. A pre-removal difference was detected only for understory density, and therefore I included the pre-removal data as a covariate in a repeated-measures ANCOVA analyses for that variable. The assumption of normality was tested using a Kolmogorov-Smirnov test ( $\alpha=0.05)$. The assumption of equality of variances was tested using an $F_{\text {max }}$ test ( $\alpha=0.05$; Sokal \& Rohlf 1995). Data were transformed as necessary using square-root, arcsine and natural $\log$ functions to conform to the assumptions of ANOVA. I also performed power analyses using GPower (Faul \& Erdfelder 1992) on each response variable that showed no response to the Sargassum muticum removal treatment. 
I performed an additional analysis on the ratio of the number of Laminaria bongardiana to the number of Agarum fimbriatum in removal experiment plots. For this analysis I only used data from the last 5 censuses in order to exclude the transitory dynamics which appeared to occur in removal plots following the removal of Sargassum muticum. Unfortunately, the large number of zeros in the data set (primarily in the control plots, where there were few kelps) precluded both the calculation of ratios and the use of ANOVA. Instead, I took the average abundance of each of the kelp species across all replicates for each treatment on each sampling date and used those averages to calculate the ratio of the 2 species for each treatment on each sampling date. Because these data points are not independent (they are repeated measures), I used the nonparametric Scheirer-Ray-Hare test (extension of the Kruskal-Wallis; Sokal \& Rohlf 1995) to determine whether the ratio of $L$. bongardiana to A. fimbriatum differed between treatments.

In addition to the ANOVA analyses, I analyzed the abundance data for a subset of the taxa from my removal experiment at Point George using structural equation modeling (SEM), a form of multiple regression related to path analysis (Hayduk 1987, Shipley 2000), to test whether the effect of Sargassum muticum on Strongylocentrotus droebachiensis was a direct or indirect effect. SEM is a type of statistical analysis in which causal relationships between variables (species in this case) are hypothesized in the form of an interaction web and tested using a system of linear equations (Hayduk 1987). Structural equation coefficients are calculated using a maximum likelihood algorithm and the significance of each coefficient is tested using multiple regression. Structural equation coefficients indicate how a change in the predictor variable would change the target variable, holding all other variables constant. The net effect of an indirect pathway between 2 species that involves multiple links can be calculated by multiplying the coefficients for the relevant links (Wootton 1994). A predicted correlation matrix between the variables is calculated based on the specified model and compared to the actual correlation matrix, using a $\chi^{2}$ distribution, to ask whether the two differ significantly. A non-significant $\chi^{2}$ statistic indicates that the causal relationships specified in the model cannot be rejected as a good caricature of the species interactions in nature. The relative fit of alternative models can be compared by comparing their $\chi^{2}$ statistics (when models are nested) as well as their Akaike information criterion (AIC) values. AIC is an information-theoretic criterion for model selection that takes into account both the goodness of fit of the model as well as the complexity of the model required to achieve that fit (Burnham \& Anderson 1998).
I used the SEM module in Statistica for Windows (Release 6.0) to estimate unstandardized structural coefficients using a maximum likelihood algorithm. The statistical significance of structural equation coefficients was determined by the software, using multiple regression for each set of dependent and independent variables. Alternative models were constructed using information from my experiments, the published literature, and my own knowledge of the natural history of the system. For the purposes of SEM analyses, I excluded canopy algae that are known to be unpalatable to Strongylocentrotus droebachiensis (Vadas 1968) because a preliminary analysis of the data from Point George indicated that urchins responded strongly to those species that are known to be preferred food items based on laboratory feeding trials (Vadas 1968) and weakly to the remaining, unpalatable species. Palatable canopy species typically contain low levels of polyphenolics, and this category included Alaria marginata, Laminaria bongardiana, L. saccharina, L. complenata and Nereocystis luetkeana. In contrast, unpalatable canopy species typically have high levels of polyphenolic compounds or other chemical defenses against herbivory, and these species included Agarum fimbriatum, A. cribrosum, Desmarestia viridis and $D$. ligulata.

I tested 2 alternative models to determine whether urchins were responding to the presence of Sargassum muticum or the absence of native algae. The presence of unpalatable $S$. muticum might directly affect urchins if their foraging behavior differs in areas with and without $S$. muticum. The presence of unpalatable algae species has been shown to alter the feeding behavior of herbivores on palatable algae when both types of algae are growing together in a phenomenon called an 'associational plant refuge' (Pfister \& Hay 1988). For example, an unpalatable congener of $S$. muticum altered the feeding behavior of the urchin Arbacia punctulata on palatable red algae when both types of algae were present (Pfister \& Hay 1988). Alternatively, $S$. muticum could indirectly affect green urchins by competing with their preferred prey species. The first model contained a direct pathway between $S$. muticum and urchins, in addition to an indirect pathway (via palatable canopy). The second model lacked the direct pathway in order to test whether removing that link altered the fit of the model to the data. Because I experimentally manipulated the presence of $S$. muticum, I included treatment as a variable in the models. I used a combination of 2 statistics to assess the fit of the models to the data: the $\chi^{2}$ test statistic and the AIC.

Strongylocentrotus droebachiensis abundance data from Point George (green urchins were not present at Colin's Cove) were analyzed separately because this 
species showed variability in abundance independent of other taxa. On many sampling dates there were no urchins in any control plot (i.e. there was no variance), precluding the use of repeated-measures ANOVA to analyze these data. Instead, I took the average across all sample dates for each plot and performed a $t$-test on the square-root transformation of these data to look for an overall effect of the treatment on average urchin abundance.

Sediment, nutrient, water flow and kelp growth data were each analyzed using a 2-way ANOVA with site and treatment as fixed factors.

Light data were analyzed using a 2-way repeatedmeasures ANOVA with site and treatment as fixed factors. Percent transmission light data were arcsin-transformed prior to analyses. I followed up the ANOVA on light data with a 1 -tailed $t$-test (because I had an a priori expectation that light would be lower in control plots than removal plots) on each sampling date to determine on which dates light differed significantly. This follow-up analysis was important because the height of the Sargassum muticum fronds in control plots varied over the course of my light measurements and I expected their effect on light to increase as they grew, and subsequently decrease as they senesced at the end of the summer. I used the sequential Bonferroni method (Sokal \& Rohlf 1995) to correct my critical $\mathrm{p}$-value for multiple comparisons within each site.

I analyzed urchin algal preference data using nonparametric statistics because transformations failed to make these data homoscedastic. I tested the null hypothesis that Strongylocentrotus droebachiensis consumed all 3 algal species presented to it equally using a Kruskal-Wallis non-parametric test. I then used nonparametric unplanned comparisons (Zar 1999) to determine how prey differed from one another.

I used a $t$-test to compare the number of urchins eaten in tanks with Sargassum muticum versus tanks containing native kelp species in order to determine whether predation risk differed between those 2 treatments. The data were log-transformed prior to analysis to achieve homoscedasticity.
Table 1. Effect of Sargassum muticum on native algae. Results of ANOVA and ANCOVA (for understory abundance) testing effect of $S$. muticum removal

\begin{tabular}{|c|c|c|c|c|c|}
\hline Source of variation & SS & df & MS & $F$ & $\mathrm{p}$ \\
\hline \multicolumn{6}{|l|}{ Canopy abundance } \\
\hline Site & 4.74 & 1 & 4.74 & 2.30 & 0.149 \\
\hline Treatment & 47.06 & 1 & 47.06 & 22.86 & 0.000 \\
\hline Site $\times$ Treatment & 3.03 & 1 & 3.03 & 1.47 & 0.242 \\
\hline Error & 32.93 & 16 & 2.06 & & \\
\hline Time & 13.50 & 13 & 1.04 & 3.90 & 0.000 \\
\hline Time $\times$ Site & 8.14 & 13 & 0.63 & 2.35 & 0.006 \\
\hline Time $\times$ Treatment & 6.65 & 13 & 0.51 & 1.92 & 0.029 \\
\hline Time $\times$ Site $\times$ Treatment & 5.59 & 13 & 0.43 & 1.61 & 0.083 \\
\hline Error & 55.40 & 208 & 0.27 & & \\
\hline \multicolumn{6}{|l|}{ Understory abundance } \\
\hline Site & 6.77 & 1 & 6.77 & 4.95 & 0.042 \\
\hline Treatment & 12.05 & 1 & 12.05 & 8.81 & 0.009 \\
\hline eatment & 0.03 & 1 & 0.03 & 0.02 & 0.889 \\
\hline Covariate (June 1999) & 8.16 & 1 & 8.16 & 5.97 & 0.027 \\
\hline Error & 20.52 & 15 & 1.37 & & \\
\hline Time & 2.37 & 9 & 0.26 & 1.87 & 0.061 \\
\hline Time $\times$ Site & 2.93 & 9 & 0.32 & 2.31 & 0.019 \\
\hline Time $\times$ Treatment & 0.51 & 9 & 0.06 & 0.40 & 0.931 \\
\hline Time $\times$ Site $\times$ Treatment & 1.38 & 9 & 0.15 & 1.09 & 0.372 \\
\hline Time $\times$ Covariate & 1.38 & 9 & 0.15 & 1.09 & 0.375 \\
\hline Error & 18.99 & 135 & 0.14 & & \\
\hline \multicolumn{6}{|l|}{ Canopy richness } \\
\hline Site & 2.75 & 1 & 2.75 & 3.77 & 0.070 \\
\hline Treatment & 10.87 & 1 & 10.87 & 14.92 & 0.001 \\
\hline Site $\times$ Treatment & 0.48 & 1 & 0.48 & 0.66 & 0.427 \\
\hline Error & 11.65 & 16 & 0.73 & & \\
\hline Time & 7.96 & 13 & 0.61 & 4.48 & 0.000 \\
\hline Time $\times$ Site & 3.25 & 13 & 0.25 & 1.83 & 0.041 \\
\hline Time $\times$ Treatment & 2.15 & 13 & 0.16 & 1.21 & 0.275 \\
\hline Time $\times$ Site $\times$ Treatment & 4.98 & 13 & 0.38 & 2.80 & 0.001 \\
\hline Error & 28.43 & 208 & 0.14 & & \\
\hline
\end{tabular}

\section{RESULTS}

\section{Removal experiments}

The structure of the native algae community was substantially altered by the removal of Sargassum muticum. Canopy algae were less abundant in control plots ( $\mathrm{p}<0.001$; Table 1, Fig. 1) and this effect did not differ between the 2 sites (Table 1). The significant time $\times$ site interaction $(p=0.006$; Table 1, Fig. 1) indicates that the temporal dynamics of canopy abundance differed between the sites and was probably caused by the somewhat delayed response of canopy algae to removal at Colin's Cove (Fig. 1). Finally, a significant time $\times$ treatment interaction $(\mathrm{p}=0.029$; Table 1, Fig. 1) showed that the difference in canopy abundance between the 2 treatments fluctuated over time, which could be explained by the slower response of canopy algae at Colin's Cove as well as the increase in canopy abundance in Colin's Cove controls in early 2000 relative to Point George. Although there was not a significant time $\times$ site $\times$ treatment interaction $(\mathrm{p}=0.083$, Table 1$)$, it did appear that the recovery of canopy algae in removal plots was delayed at Colin's Cove relative to Point George (Fig. 1). Despite this possible difference in the timing of recovery, native canopy algae were 4 to 5 times as abundant in removal plots compared to control plots at both sites by the last census date. 
Understory algae were also less abundant in control plots ( $p=0.009$; Table 1, Fig. 2) and this effect did not differ between sites (Table 1). Including pre-removal understory abundance as a covariate explained a significant amount of variation in the ANCOVA model $(p=0.027$; Table 1$)$. As with the data for canopy algae, there was a significant time $\times$ site interaction $(p=0.019$; Table 1), which was probably caused by the somewhat delayed recovery of understory algae in removal plots at Colin's Cove (Fig. 2). Although the recovery of understory algae at Colin's Cove lagged behind that at Point George slightly, by the end of the experiment understory algae were twice as abundant in removal plots as control plots at both sites compared to a similar $100 \%$ initial difference at Point George and a $62 \%$ initial difference at Colin's Cove.

Native canopy richness was lower in control plots than removal plots ( $p=0.001$; Table 1, Fig. 3). On average, Sargassum muticum displaced 1 native species at both sites. As was the case for canopy and understory abundance, a significant time $\times$ site interaction $(\mathrm{p}=0.041$; Table 1$)$ probably was caused by the somewhat delayed recovery of canopy algae in removal

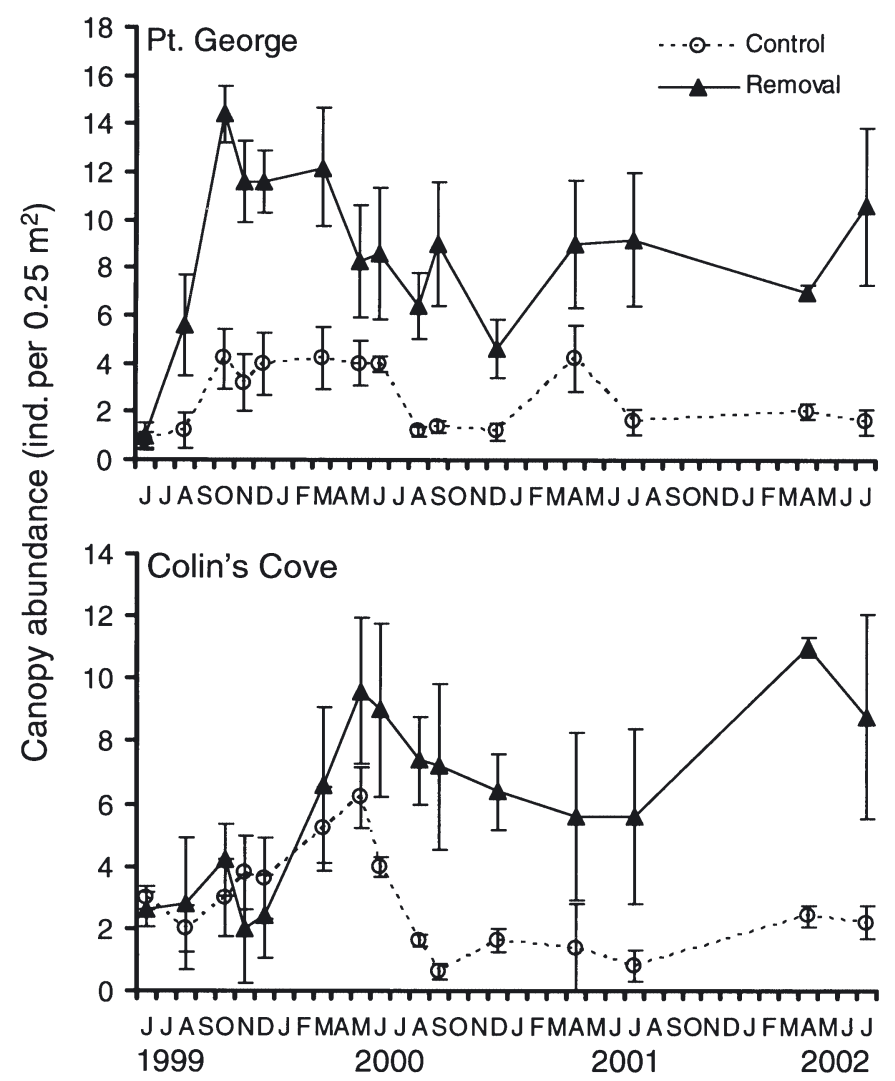

Fig. 1. Abundance (mean $\pm \mathrm{SE}$ ) of native canopy algae in Sargassum muticum removal experiments at Point George and Colin's Cove $(n=5)$. First data point in each series is for pre-removal census
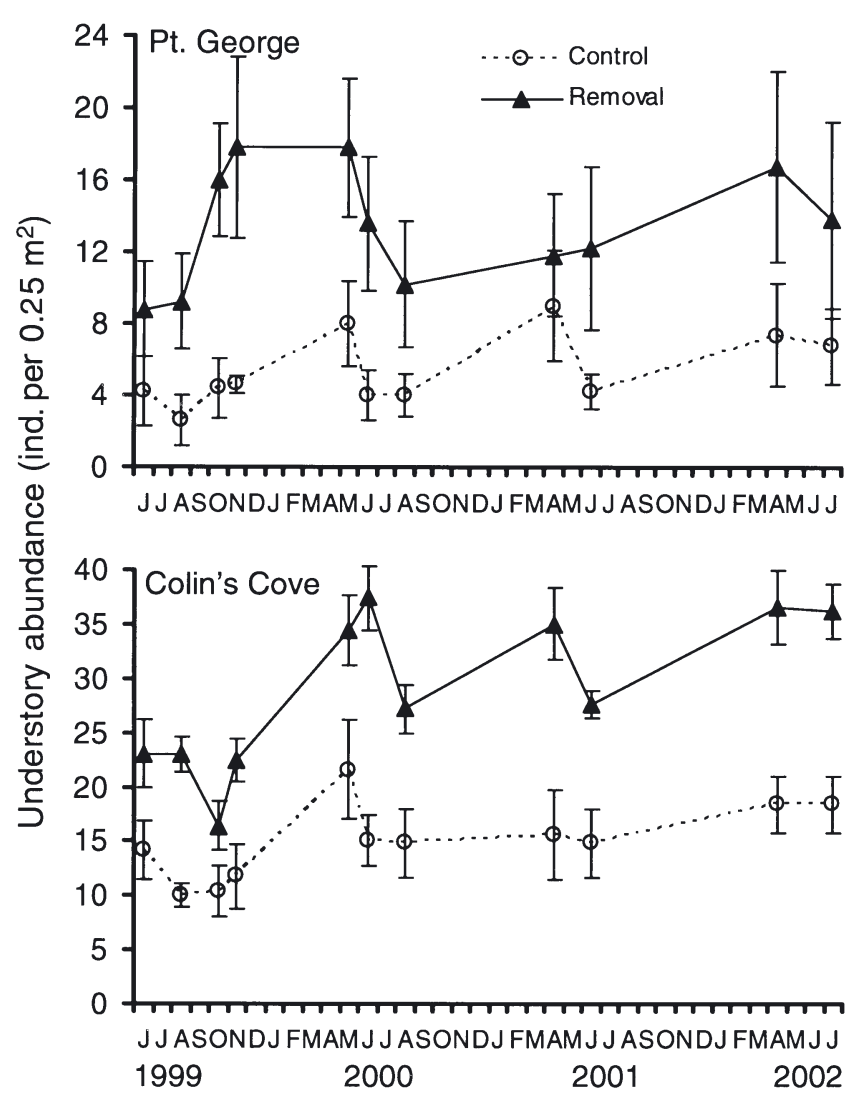

Fig. 2. Abundance (mean $\pm \mathrm{SE}$ ) of native understory algae in Sargassum muticum removal experiments at Point George and Colin's Cove $(n=5)$. First data point in each series is for pre-removal census

plots at Colin's Cove (Fig. 3). Finally, the significant time $\times$ site $\times$ treatment interaction $(p=0.001$; Table 1$)$ was caused by a lack of concordance in the temporal dynamics of the treatment effect at the 2 sites. During 1999, the control and removal means diverged at Point George but remained roughly equal at Colin's Cove (Fig. 3). The following year, in 2000, the treatment means at Point George began to converge again while those at Colin's Cove had just begun to diverge (Fig. 3).

The relative abundance of the 2 most common native kelp species, Laminaria bongardiana and Agarum fimbriatum, differed between control and removal plots. The ratio of $L$. bongardiana to A. fimbriatum was lower in control plots, where Sargassum muticum was present (Scheirer-Ray-Hare extension of the KruskalWallis test, $H=7.22, \mathrm{p}<0.01$; Fig. 4). This effect did not differ between sites $(H=0.63, \mathrm{p}<0.5)$, and there was no indication of a site $\times$ treatment interaction $(H=0.37, \mathrm{p}<0.9)$.

The abundance of green urchins was negatively affected by the presence of Sargassum muticum. Although there were no urchins in any plot during the first summer of the experiment, a year later they had 
begun to forage regularly in removal plots at Point George (Fig. 5). Their absence during the first summer of the experiment probably reflects the near-absence of kelps, their preferred food, in experimental plots. The appearance of urchins in removal plots was preceded by an increase in canopy algae in removal plots at Point George (Fig. 1). A $t$-test on the average Strongylocentrotus droebachiensis abundance across

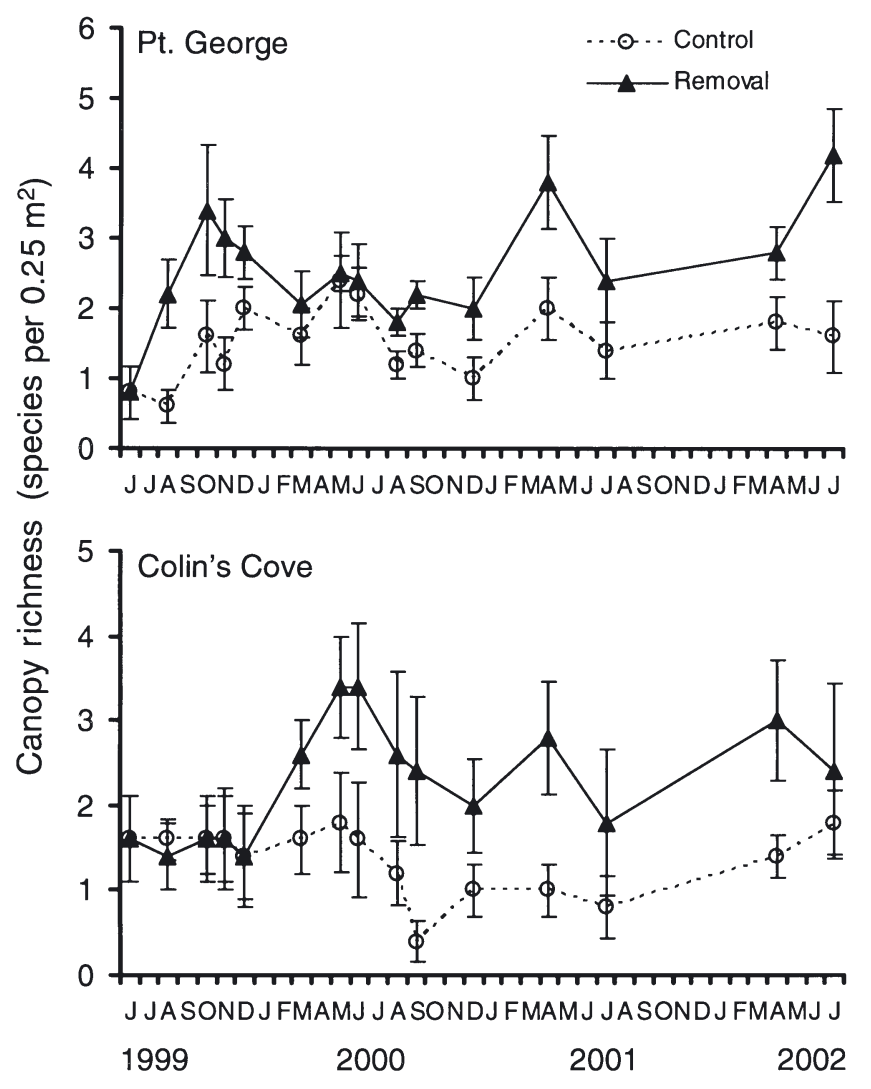

Fig. 3. Species richness (mean $\pm \mathrm{SE}$ ) of native canopy algae in Sargassum muticum removal experiments at Point George and Colin's Cove $(n=5)$. First data point in each series is for pre-removal census

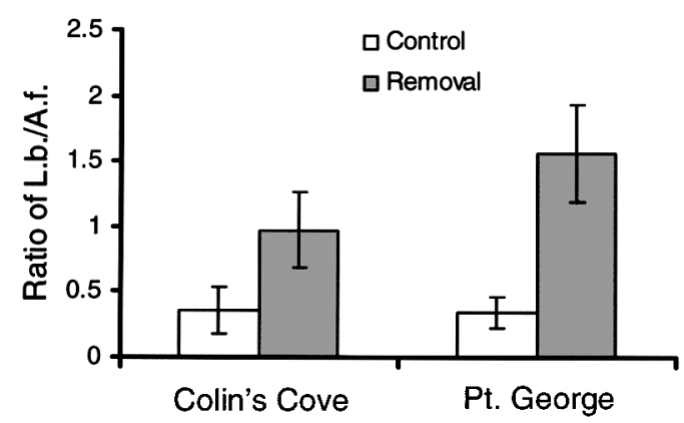

Fig. 4. Ratio of the number of Laminaria bongardiana (L.b.) to the number of Agarum fimbriatum (A.f.) ( $\mathrm{n}=5)$. Both species are native kelps all sample dates for each plot showed that urchins were significantly more abundant in removal plots than control plots $\left(t_{8}=-6.34, \mathrm{p}<0.001\right.$; Fig. 5$)$ at Point George. Green urchins were never observed at Colin's Cove, but red urchins ( $S$. franciscanus) were present at deeper depths at that site throughout the experiment.

Several variables showed no response to Sargassum muticum manipulation. I found no evidence that $S$. muticum altered the percent cover of crustose coralline algae, filamentous turf-forming algae, or bare rock (Table 2). Similarly, there was no evidence for an effect of $S$. muticum on the abundance of detritivores, the abundance of herbivorous molluscs, or the species richness of the invertebrate community (Table 2). Power analysis revealed that I had low statistical power to detect effects on some of these variables (Table 2). However, in several cases (bare rock, crustose algae and invertebrate richness) the extremely small effect sizes involved would have made it difficult to detect a significant effect, even if a more powerful experimental design had been employed. In the case of turf-forming algae, it appears that a large amount of variation may have obscured the effect of $S$. muticum (Table 2).

The results of the structural equation modeling (SEM) are presented in Fig. 6. Structural equation coefficients (values next to arrows in Fig. 6) indicate the sign and strength of the effect of one variable on another. More specifically, each coefficient indicates the change in abundance of the dependent variable that would result from a 1-unit change in the predictor variable. Thick arrows indicate statistically significant pathways $(p<0.05)$ and thin arrows indicate nonsignificant paths.

The SEM results suggest that the effect of Sargassum muticum on green urchins was an indirect effect,

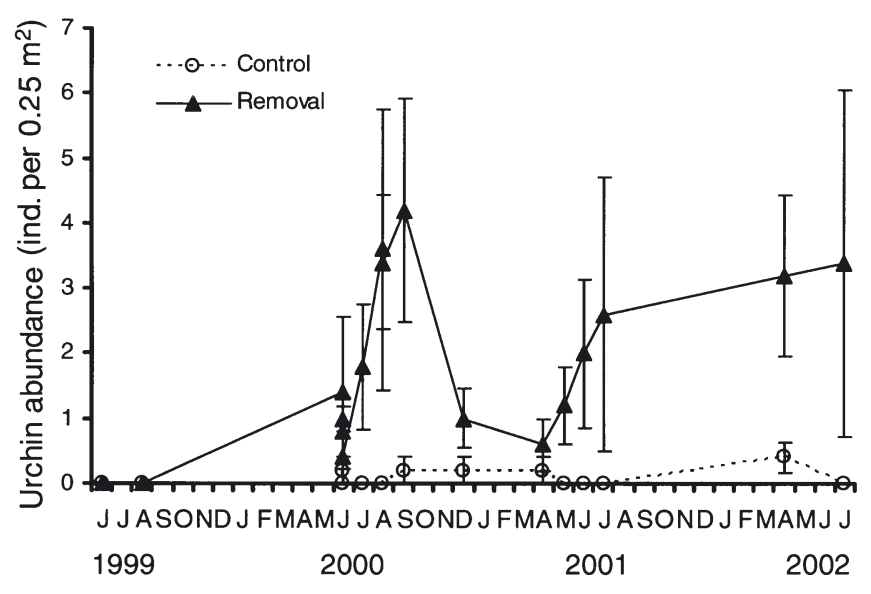

Fig. 5. Strongylocentrotus droebachiensis. Abundance (mean \pm SE) in Sargassum muticum removal experiment at Point George $(n=5)$. First data point in each series is for preremoval census 
Table 2. Response variables that showed no statistically significant $(\alpha=0.05)$ response to removal of Sargassum muticum (n $=5$ for each mean). Rock, turf-forming algae and coralline algae data are \% cover. All abundance data are means \pm 1 SE for each experimental plot averaged across all sampling dates. Power $=1-\beta$, or probability of correctly rejecting $H_{\mathrm{o}}$ if it were false

\begin{tabular}{|lrrrrr|}
\hline \multirow{2}{*}{ Variable } & \multicolumn{2}{c}{ Point George } & \multicolumn{2}{c}{ Colin's Cove } \\
& Control & Removal & Control & Removal \\
\hline Bare rock & $4.9 \pm 2.3$ & $12.1 \pm 3.4$ & $7.9 \pm 4.3$ & $1.1 \pm 0.6$ & 0.05 \\
Crustose coralline algae & $21.5 \pm 7.9$ & $34.1 \pm 9.0$ & $18.7 \pm 6.1$ & $20.1 \pm 5.9$ & 0.20 \\
Turf-forming algae & $49.1 \pm 8.8$ & $34.5 \pm 8.3$ & $53.5 \pm 7.7$ & $42.4 \pm 5.1$ & 0.40 \\
Invertebrate richness & $7.1 \pm 0.6$ & $7.8 \pm 0.4$ & $4.7 \pm 0.5$ & $4.7 \pm 0.6$ & 0.07 \\
Detritivores & $13.5 \pm 3.0$ & $5.8 \pm 1.4$ & $6.1 \pm 1.4$ & $6.8 \pm 2.0$ & 0.54 \\
Herbivorous molluscs & $7.0 \pm 1.0$ & $11.0 \pm 0.9$ & $4.0 \pm 1.1$ & $4.0 \pm 1.2$ & 0.62 \\
\hline
\end{tabular}

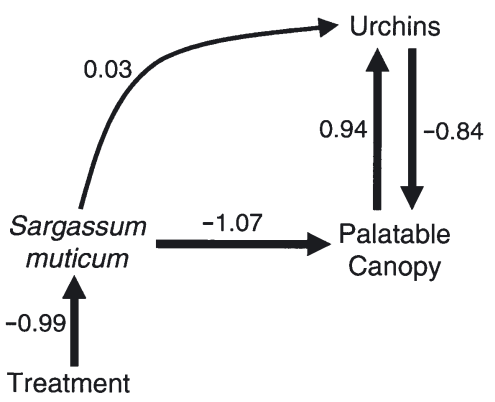

Fig. 6. Structural equation model for Point George data in Sargassum muticum removal experiment (urchins = Strongylocentrotus droebachiensis; palatable canopy = Laminaria bongardiana, L. complenata, Alaria marginata, Nereocystis luetkeana). Arrows indicate direction of causality. Thick arrows indicate statistically significant $(\mathrm{p}<0.05)$ paths from multiple-regression analysis; structural equation coefficients are shown next to each arrow. Removing direct link between $S$. muticum and urchins did not change model fit or values of the remaining coefficients. Observed correlation matrix did not differ significantly from that predicted by model $\left(\chi_{2}^{2}=5.08, p=0.08\right.$; Akaike information criterion, $\left.\mathrm{AIC}=0.267\right)$

not a direct effect (Fig. 6). The direct pathway from $S$. muticum to urchins was very weak and was not statistically significant (coefficient $=0.03, p=0.90$; Fig. 6). In contrast, the net effect of the indirect pathway from $S$. muticum to urchins, obtained by multiplying the coefficients for each of the links involved (Wootton 1994), was very strong $(-1.07 \times 0.94=-1.01)$ and both of the component pathways ( $S$. muticum to palatable canopy and palatable canopy to urchins) were statistically significant. Removing the direct link between $S$. muticum and urchins did not change the model fit or the values of the remaining coefficients. In fact, the 2 models were statistically indistinguishable $\left(\chi_{2}^{2}=5.08, \mathrm{p}=0.08\right.$, $\mathrm{AIC}=0.267$ for both models), providing additional evidence that the direct effect of $S$. muticum on urchins was negligible. In summary, the SEM analysis suggests that the negative effect of $S$. muticum on urchins was an indirect effect that also involved palatable canopy algae (Fig. 6).

\section{Light}

The overall ANOVA on light data from both sites indicated a highly significant effect of treatment ( $p<0.001$; Table 3, Fig. 7) on light transmittance, and this effect did not differ between the 2 sites $(p=0.570$; Table 3). These results reflect the fact that light intensity was (on average) more intense in removal plots than control plots at both sites (Fig. 7), even though the absolute difference between treatments varied over time as Sargassum muticum's fronds grew, matured, and senesced. There was also a significant site effect $(p=0.001$; Table 3$)$, with percent transmission of light at Point George higher than at Colin's Cove (Fig. 7). This systematic difference is probably due to the fact that the shoreline at Point George faces W-SW and receives more intense sunlight than the E-facing shore at Colin's Cove. Finally, a significant time $\times$ treatment interaction ( $p<0.001$; Table 3 ) indicated that the treatment effect changed over time. To determine when significant differences in light level occurred, I followed up this analysis with $t$-tests on each sampling date within the 2 sites. A 1 -tailed $t$-test on each date revealed that light transmittance was lower in control plots at both sites in May $(\mathrm{p}<0.05$ and $\mathrm{p}<0.01$ at Point George and Colin's Cove, respectively; Fig. 7) and June ( $p<0.001$ at Point George and Colin's Cove; Fig. 7).

Table 3. Results of ANOVA testing effect of Sargassum muticum on light transmittance in removal experiments

\begin{tabular}{|lrrrrr|}
\hline Source of variation & SS & df & MS & $F$ & $\mathrm{p}$ \\
\hline Site & 0.128 & 1 & 0.128 & 16.07 & 0.001 \\
Treatment & 0.251 & 1 & 0.251 & 31.54 & 0.000 \\
Site $\times$ Treatment & 0.003 & 1 & 0.003 & 0.34 & 0.570 \\
Error & 0.127 & 16 & 0.008 & & \\
Time & 0.696 & 3 & 0.232 & 70.75 & 0.000 \\
Time $\times$ Site & 0.009 & 3 & 0.003 & 0.95 & 0.423 \\
Time $\times$ Treatment & 0.239 & 3 & 0.080 & 24.31 & 0.000 \\
Time $\times$ Site $\times$ Treatment & 0.021 & 3 & 0.007 & 2.18 & 0.103 \\
Error & 0.157 & 48 & 0.003 & & \\
\hline
\end{tabular}




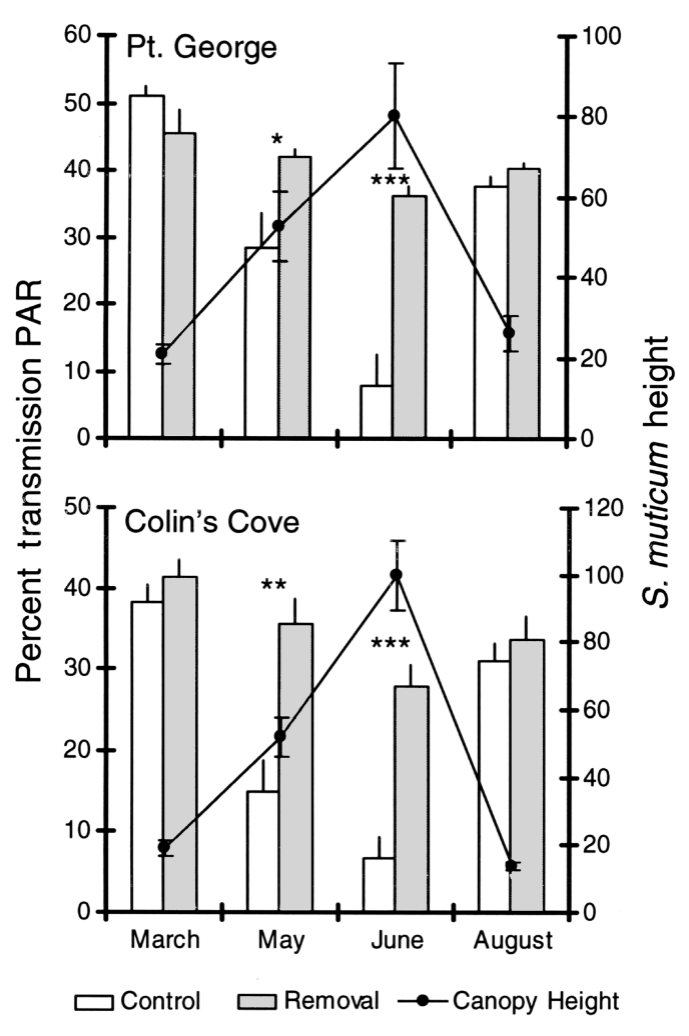

Fig. 7. Percent transmission (mean \pm SE) of photosynthetically active radiation (400 to $700 \mathrm{~nm}$, PAR) in Sargassum muticum removal experimental plots at Point George and Colin's Cove in 2000. Secondary $y$-axis shows height of $S$. muticum ( \pm SE) in control plots at time each set of light measurements was taken. Asterisks indicate sample dates where $t$-test indicated significant difference between treatments $\left({ }^{*},{ }^{* *},{ }^{* * *}: \mathrm{p}<0.05\right.$, 0.01 , and 0.001 , respectively)

\section{Water flow}

I found no evidence that the Sargassum muticum removal treatment had an effect on water flow at a distance of $30 \mathrm{~cm}$ above the substratum (ANOVA, $F_{1,15}=0.04, \mathrm{p}=0.85$; Fig. 8). However, water flow at Point George was considerably higher than at Colin's Cove (ANOVA, $F_{1,15}=65.29, \mathrm{p}<10^{-5}$; Fig. 8). There was no evidence of a site $\times$ treatment interaction.

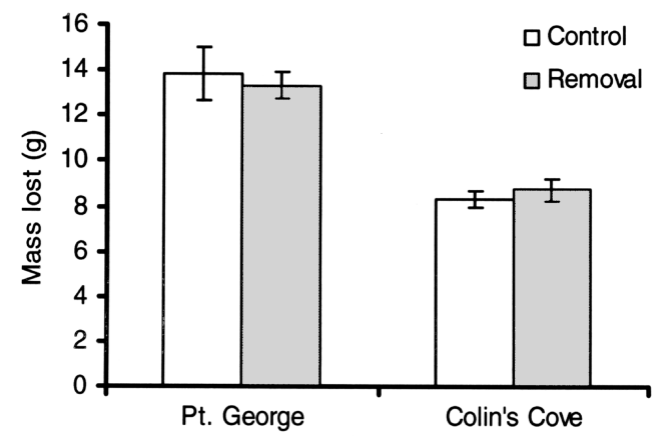

Fig. 8. Dissolution of gypsum blocks (mean \pm SE) in experimental plots where Sargassum muticum was present (Control) and in plots from which it had been removed (Removal)

more numerous in removal plots (Figs. 1 \& 2). The deposition of organic sediment was not different in control and removal plots (ANOVA, $F_{1,14}=3.73, \mathrm{p}=$ 0.074; Fig. 9). The deposition of inorganic sediment did not differ between the treatments either (ANOVA, $\left.F_{1,14}=0.43, p=0.524\right)$, but there was a significant site $\times$ treatment interaction for this response variable (ANOVA, $\left.F_{1,14}=5.42, \mathrm{p}=0.035\right)$. This interaction probably occurred because inorganic sedimentation tended to be slightly higher in removal plots than control plots at Point George, but higher in control than removal plots at Colin's Cove (Fig. 9). Finally, total sediment deposition did not differ between the 2 treatments (ANOVA, $F_{1,14}=0.96, \mathrm{p}=0.344$ ), but it also showed some suggestion of a site $\times$ treatment interaction (ANOVA, $\left.F_{1,14}=4.37, \mathrm{p}=0.055\right)$, which likely resulted for the same reason stated above for inorganic sedimentation. Overall, there was no indication that $S$. muticum removal had an effect on sedimentation by the time that native algae had recovered to replace the $S$. muticum that had been removed 2 yr earlier.

\section{Nutrients}

None of the 5 nutrients assayed differed between control and removal plots (Table 4) (ANOVA, $F_{1,16}$

\section{Sedimentation}

Analysis of sedimentation data collected in July 2001 yielded no evidence that Sargassum muticum altered sedimentation rates. At the time these data were collected, canopy and understory algae had already responded to the $S$. muticum removal treatment, with both types of algae
Table 4. Nutrient concentrations ( $\mu$ M means $\pm 1 \mathrm{SE}$ ) of water samples taken from Sargassum muticum removal experiment plots ( $\mathrm{n}=5$ for each mean)

\begin{tabular}{|lrrrr|}
\hline \multirow{2}{*}{ Nutrient } & \multicolumn{2}{c}{ Point George } & \multicolumn{2}{c|}{ Colin's Cove } \\
& \multicolumn{1}{c}{ Control } & \multicolumn{1}{c|}{ Removal } & \multicolumn{1}{c|}{ Control } & \multicolumn{1}{c|}{ Removal } \\
\hline $\mathrm{PO}_{4}$ & $1.96 \pm 0.012$ & $1.97 \pm 0.007$ & $1.91 \pm 0.007$ & $1.89 \pm 0.013$ \\
$\mathrm{Si}(\mathrm{OH})_{4}$ & $49.05 \pm 0.256$ & $48.56 \pm 0.195$ & $46.97 \pm 0.236$ & $47.04 \pm 0.113$ \\
$\mathrm{NO}_{3}$ & $22.47 \pm 0.088$ & $22.46 \pm 0.129$ & $21.88 \pm 0.096$ & $21.67 \pm 0.374$ \\
$\mathrm{NO}_{2}$ & $0.31 \pm 0.003$ & $0.30 \pm 0.002$ & $0.30 \pm 0.002$ & $0.30 \pm 0.002$ \\
$\mathrm{NH}_{4}$ & $0.52 \pm 0.015$ & $0.53 \pm 0.021$ & $0.57 \pm 0.010$ & $0.54 \pm 0.028$ \\
\hline
\end{tabular}




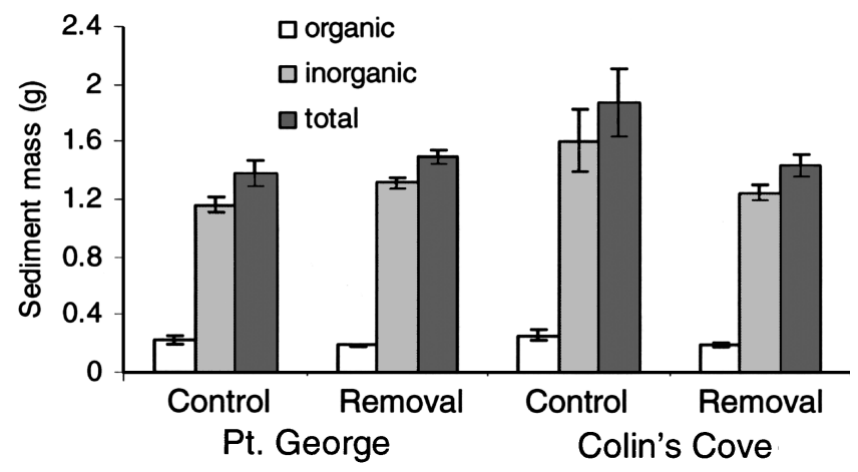

Fig. 9. Sediment accumulation (mean \pm SE) in traps placed in experimental plots at Point George and Colin's Cove where Sargassum muticum was present (Control) and in plots from which it had been removed (Removal). Total sediment is sum of organic and inorganic components of sediment

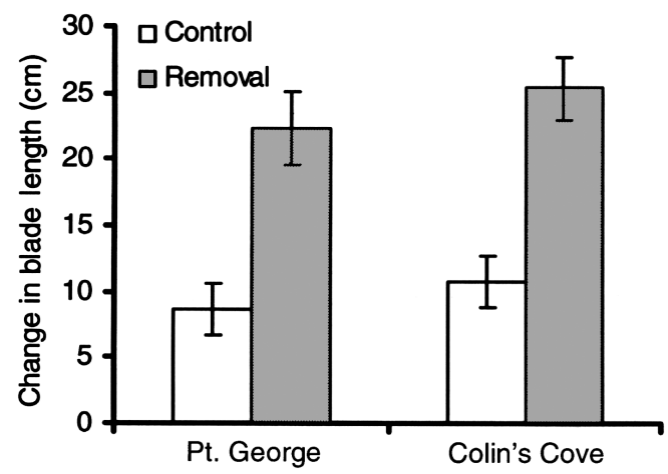

Fig. 10. Laminaria bongardiana. Growth (mean $\pm \mathrm{SE}$ ) of native kelp in plots where Sargassum muticum was present (Control) and plots from which it had been removed (Removal) at Point George and Colin's Cove $(\mathrm{n}=5)$

$\mathrm{p}>0.30$ in every case). However, phosphate (ANOVA, $F_{1,16}=40.24, \mathrm{p}<0.001$ ), silicate (ANOVA, $F_{1,16}=75.18$, $\mathrm{p}<0.001$ ) and nitrate (ANOVA, $F_{1,16}=10.92, \mathrm{p}<0.01$ ) concentrations were significantly higher at Point George (Table 4). Since water samples were taken on different (but consecutive) days at each site, these site differences may reflect day-to-day fluctuations as water masses move through this region.

\section{Kelp growth}

Each plot began the kelp growth experiment with 3 Laminaria bongardiana, but several plots lost 1 or more plants during the course of the experiment. I averaged the results for all surviving plants within each plot and used those means in the statistical analysis. Thus, the extra plants in each plot increased the accuracy of the growth measurements but did not increase the number of replicates. At Colin's Cove, 1 of the control plots lost all its plants, and consequently there were only 4 control replicates from that site. There was no statistically significant relationship between site (ANOVA, $\mathrm{p}=$ 0.826 ) or treatment (ANOVA, $p=0.826$ ) and the number of plants lost. Likewise, there was no relationship between the number of plants lost and growth of the remaining kelps $\left(\mathrm{R}_{1,17}^{2}=0.13, \mathrm{p}=0.133\right)$.

Linear blade growth of Laminaria bongardiana was 2 to 3 times faster in plots from which Sargassum muticum was absent than in those where it was present (ANOVA, $F_{1,15}=25.95, \mathrm{p}<0.001$; Fig. 10). Growth did not differ between the 2 sites (ANOVA, $F_{1,15}=0.20, p>$ 0.30 ) and there was no site $\times$ treatment interaction (ANOVA, $F_{1,15}=0.11, \mathrm{p}>0.73$ ). Analysis of blade area and kelp mass data yielded comparable results (data not shown).

\section{Urchin food preferences}

Strongylocentrotus droebachiensis distinguished among the 3 species of algae that were presented to it in the preference experiment (Kruskal-Wallis, $p=$ 0.001; Fig. 11). Non-parametric unplanned comparisons (Zar 1999) showed that Laminaria bongardiana was preferred over both Agarum fimbriatum $(p<0.01)$ and Sargassum muticum $(\mathrm{p}<0.005)$, but that A. fimbriatum and $S$. muticum were equally ignored. This experiment supported the hypothesis that green urchins do not feed on $S$. muticum in the field because they found its tissue unpalatable. Nevertheless, even if they find $S$. muticum palatable its morphology could prevent them from effectively exploiting it as a food resource in the field.

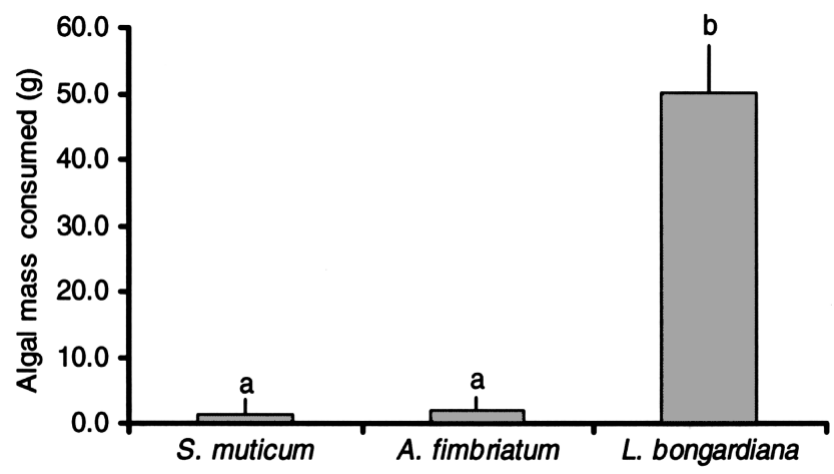

Fig. 11. Algal mass (mean $+\mathrm{SE}$ ) consumed by native sea urchin Strongylocentrotus droebachiensis in food choice experiment where 2 native kelps (Laminaria bongardiana and Agarum fimbriatum) and Sargassum muticum were offered simultaneously. Letters indicate which means differ significantly (non-parametric unplanned comparisons) 


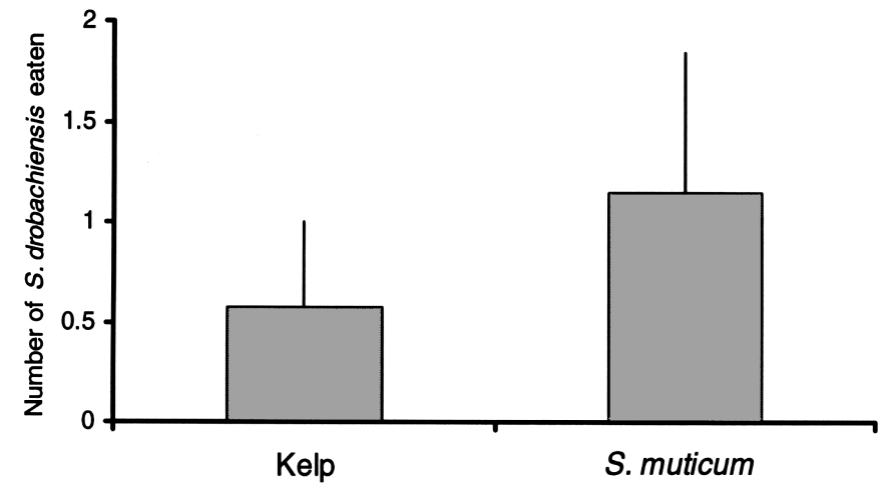

Fig. 12. Strongylocentrotus droebachiensis. Number of green urchins (mean + SE) eaten by sea star Pycnopodia helianthoides in tanks containing Sargassum muticum monoculture or mixture of native kelp species $(n=7)$

\section{Urchin predation}

The sea star predation hypothesis was not supported by experimental data. There was no difference in predation by Pycnopodia helianthoides on Strongylocentrotus droebachiensis between the Sargassum muticum and mixed-kelp treatments $(t=-0.632, \mathrm{p}=0.545$; Fig. 12). While the average number of urchins visible ( $\geq 25 \%$ of test) was greater on Days 3 and 8 (Fig. 13), repeated-measures ANOVA analysis indicated no statistically significant difference between treatments $\left(F_{1,12}=4.30, \mathrm{p}=0.06\right)$. There was a significant effect of time in the ANOVA model $\left(F_{1,12}=15.87, \mathrm{p}=0.002\right)$, which resulted because both treatments means decreased between the 2 sampling dates (Fig. 13). Although there was no significant time $\times$ treatment

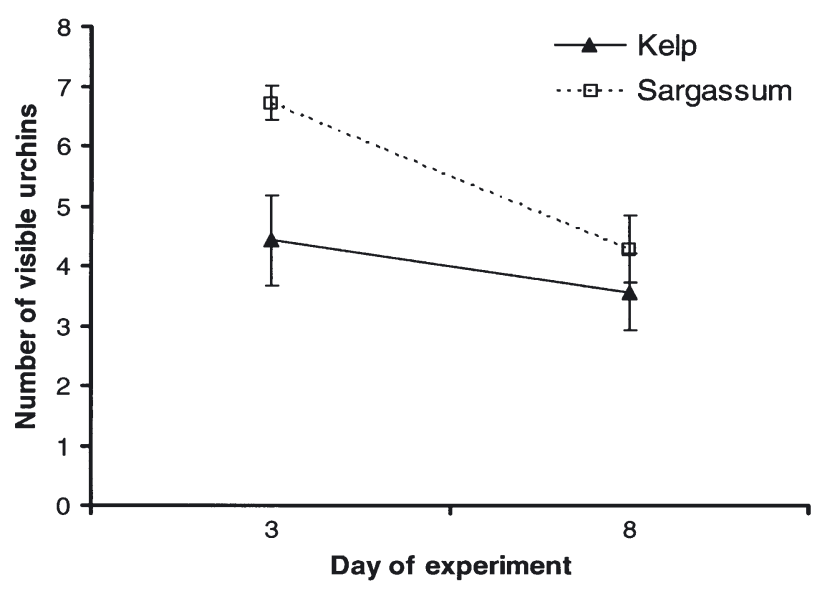

Fig. 13. Strongylocentrotus droebachiensis. Number of visible green urchins (mean $\pm \mathrm{SE}$ ) in tanks containing mixture of native kelps versus tanks containing Sargassum muticum $(\mathrm{n}=7)$. Treatment means differed on Day $3(t$-test, $\mathrm{p}=0.01)$ but not on Day 8 ( $t$-test, $\mathrm{p}=0.42$ ) interaction $\left(F_{1,12}=4.32, \mathrm{p}=0.08\right)$, the difference between the 2 treatments did appear to decline from Days 3 to 8 (Fig. 13). Despite the absence of an overall difference between treatments, further analysis showed that significantly more urchins were visible in the $S$. muticum treatment on Day $3(t=-2.843, \mathrm{p}=$ 0.01 ), but that this difference had dissipated by Day 8 $(t=-0.830, \mathrm{p}=0.42)$. Even though there was little difference between the treatments at the end of the experiment (Day 8), it does appear that a higher proportion of urchins in the kelp treatment were hidden for the majority of the experiment (Fig. 13). Contrary to expectation, the urchins in the kelp treatment were not less vulnerable to sea star predation (Fig. 12). This experiment does provide some evidence that green urchins can more easily hide themselves in algal canopies dominated by native kelps than in those dominated by $S$. muticum. Furthermore, these data are a conservative indication of the differential use of $S$. muticum and kelps by urchins, because in this laboratory experiment urchins were able to make use of $S$. muticum in a way they cannot commonly do in the field. Most of the urchins that managed to hide themselves in the $S$. muticum treatment did so by climbing the walls of the tank, grasping onto the fronds of nearby $S$. muticum, and using those fronds to cover their tests (own pers. obs.). Although S. muticum does grow adjacent to vertical rock surfaces in the field at some sites (e.g. at the base of walls or next to large boulders), these places are relatively rare and I have never observed green urchins using $S$. muticum to hide themselves in this manner in the field. Overall, the results of this experiment suggest that increased predation by sea stars in $S$. muticum-dominated areas cannot explain why green urchins were less abundant in control plots in the $S$. muticum removal experiment.

\section{DISCUSSION}

Removal experiments showed that Sargassum muticum has substantial direct effects on the native algae community characteristic of the San Juan Islands. Competition with $S$. muticum reduced the abundance of native canopy algae by approximately $75 \%$ and native understory algae by about $50 \%$ (Figs. 1, 2 \& 6). $S$. muticum also displaced (on average) 1 native species of canopy algae (Fig. 3), thereby reducing the species richness of native canopy species, but leaving total algal richness unchanged. However, the negative effect on species richness that occurred at the small scale of my experimental plots $\left(0.25 \mathrm{~m}^{2}\right)$ may not be important at larger scales.

In addition to affecting the abundance and richness of native canopy algae, Sargassum muticum changed 
the relative abundance of the 2 most common native kelp species, Laminaria bongardiana and Agarum fimbriatum. L. bongardiana was relatively less abundant in plots where S. muticum was present (Fig. 4). This result was probably caused by interspecific differences in light requirements. Laminaria bongardiana is a species that has few chemical defenses (Hammerstrom et al. 1998), grows relatively fast, is found only in the shallow subtidal zone (own pers. obs.), and grows more slowly when transplanted beneath $S$. muticum (Fig. 10). A. fimbriatum, on the other hand, has high concentrations of polyphenolics to deter herbivory (Hammerstrom et al. 1998), grows relatively slowly, and is the deepest-occurring kelp species in this region (commonly found at depths of $15 \mathrm{~m}$ or more; own pers. obs.). Thus, L. bongardiana is probably more sensitive than $A$. fimbriatum to the shading caused by $S$. muticum (Fig. 7), and was relatively less abundant in control plots as a result.

Field measurements suggest that the effects of Sargassum muticum on macroalgae are probably a result of shading (Fig. 7). There was no evidence that $S$. muticum had an effect on nutrients (Table 4), and because algae in this region do not appear to be nutrientlimited (Wootton 1991, Pfister \& Van Alstyne 2003) it is unlikely that competition for nutrients plays an important role in these interactions. However, my limited sampling of water flow (Fig. 8) and sedimentation (Fig. 9) makes it difficult to rule out these factors completely, and other resources I did not take into account (e.g. space) could also be important.

Structural equation modeling (SEM) showed that Sargassum muticum-induced changes in palatable canopy algae had an important indirect effect on a native herbivore, the green sea urchin Strongylocentrotus droebachiensis (Fig. 6). Green urchins were not recorded in experimental plots at either site during the first year of the experiments (Fig. 5), although they were present at Point George at depths deeper than my experiments (own pers. obs.). However, by the summer of 2000, green urchins had begun foraging regularly in the removal plots at Point George, where a robust community of kelps and red algae had developed following the removal of $S$. muticum (Fig. 5). It appears that green urchins avoided control plots because the kelp genera Laminaria, Alaria and Nereocystis, which are their preferred food (Fig. 11 and Vadas 1968, 1977, Larson et al. 1980), were less abundant due to competition with $S$. muticum (Fig. 1).

I also tested 2 additional hypotheses that might explain why green urchins avoided plots where Sargassum muticum was abundant: (1) The presence of unpalatable $S$. muticum could reduce grazing by sea urchins on nearby palatable native species (so-called associational plant refuge; e.g. Pfister \& Hay 1988). In this scenario, palatable algae gain protection from herbivores when they are spatially associated with unpalatable algae because herbivores avoid foraging in areas where the unpalatable species are present. This hypothesis was not supported by SEM analyses of my removal experiment data (Fig. 6). (2) Algal canopies dominated by $S$. muticum could enable the sea star Pycnopodia helianthoides (a locally common green urchin predator) to prey more effectively on green urchins. Green urchins typically cover their aboral surface with kelp or other algae while feeding, but $S$. muticum's positively buoyant fronds and wiry morphology could make it unsuitable for this purpose. Therefore, green urchins might be more vulnerable to predation by foraging sea stars in areas where $S$. muticum is the dominant alga. A laboratory experiment designed to test this hypothesis showed that although green urchins seemed better able to conceal themselves when feeding on native kelps compared to S. muticum (Fig. 13), there was no difference in sea star $(P$. helianthoides) predation between the 2 treatments (Fig. 12). My conclusion that $S$. muticum negatively affects urchins is in accordance with a study of S. muticum in California tidepools that found a similar result for a congener, Strongylocentrotus purpuratus (Wilson 2001). However, the indirect effect that was the cause of the negative effect on urchins in my system has not been demonstrated in any previous study.

Although the removal experiments at Point George and Colin's Cove yielded largely similar results, there were some notable differences between the 2 sites. For example, the recovery dynamics of canopy algae following the removal of Sargassum muticum differed between them (Fig. 1). Whereas the recovery at Point George was rapid, it was considerably delayed at Colin's Cove. Source-populations of native canopy and understory species were only 2 to $3 \mathrm{~m}$ deeper than my experimental plots at both sites. Under most conditions, kelps are unlikely to be strongly dispersallimited over this distance (Reed et al. 1988, Fredriksen et al. 1995, Forrest et al. 2000). Nevertheless, stronger tidal currents at Point George (Fig. 8) may have facilitated the dispersal of algae into plots from which $S$. muticum had been removed.

The presence of green urchins at Point George but not Colin's Cove was another source of variation between sites. These urchins can be locally abundant, but have a discontinuous distribution across sites. Thus it is not surprising that they were present at only 1 of my sites. Canopy algae abundance in removal plots at Point George decreased following the arrival of urchins at that site in the spring of 2000 (Fig. 1). Native canopy algae richness was higher in the absence of Sargassum muticum at both sites, but urchin grazing in the removal plots at Point George caused a decline in 
canopy richness during 2000 and briefly led to the convergence of control and treatment dynamics at that site (Fig. 3).

Because kelps are the numerically and physically dominant plants in these algal communities, it would be useful to know whether only 1 or both phases of their life cycles are affected by Sargassum muticum. The lowest light levels I recorded in plots containing S. muticum (29 and $36 \mu \mathrm{E} \mathrm{m} \mathrm{m}^{-2} \mathrm{~s}^{-1}$ at Colin's Cove and Point George, respectively) are below the threshold at which light limitation in kelp sporophytes is expected (150 to $200 \mu \mathrm{E} \mathrm{m} \mathrm{m}^{-2} \mathrm{~s}^{-1}$, Lüning 1981), and growth experiments clearly showed that sporophytes grew more slowly under the S. muticum canopy (Fig. 10). However, these light levels exceed the threshold where kelp gametophytes are saturated for vegetative growth $\left(20 \mu \mathrm{E} \mathrm{m}^{-2} \mathrm{~s}^{-1}\right.$, Lobban \& Harrison 1994). Thus, the effect of $S$. muticum on the kelp component of the algal community is probably due to its impact on the sporophyte phase, not the gametophyte phase of the kelp life cycle. One important caveat to this conclusion is that my light measurements reflect maximum irradiance values because the data were taken at midday; average light intensity was undoubtedly much lower.

In general, many species of native algae are likely to be affected due to shading by Sargassum muticum because of the timing of its life cycle in this region. The fronds of $S$. muticum usually begin growing in early March each year, and in 2000 it was already having a significant effect on light by mid-May (Fig. 7). Although some perennial kelp species are capable of reproducing in the winter (e.g. Agarum fimbriatum and Laminaria bongardiana; Vadas 1968, and own pers. obs.) many annual kelps (e.g. Costaria costata) must reproduce in the spring and summer. Furthermore, most native red algae (i.e. understory algae) are either only present during the spring and summer, or experience most of their growth during that time (own pers. obs.). The months during which $S$. muticum is having its strongest effect on light (Fig. 7) is also a critical period of time for the growth and reproduction of many species of native algae.

Previous studies of Sargassum muticum have varied widely in their conclusions about its effect on native communities. However, my study is in accordance with 1 generalization that emerges from a review: studies in the intertidal zone have found little or no impact of S. muticum (DeWreede 1983, DeWreede \& Vandermeulen 1988, Viejo 1997, Wilson 2001), but studies in the subtidal zone indicate relatively strong effects (Ambrose \& Nelson 1982, Staehr et al. 2000, present study). Considering the vertical distribution of $S$. muticum, this general trend is not surprising. The lower intertidal is at the upper edge of S. muticum's vertical distribution (DeWreede 1983, Staehr et al.
2000, own pers. obs.), where it is susceptible to desiccation and frost (Norton 1977), and it generally reaches lower densities in the intertidal compared with the subtidal, even in tidepools (Wilson 2001, own pers. obs.). Thus, one might expect it to have less of an impact on native species in the intertidal simply because it is less abundant there.

Although different sites in the San Juan Islands vary considerably in the density of Sargassum muticum they contain, it is extremely difficult to find sites which it has not yet invaded (own pers. obs.). Given the results of these experiments, 2 impacts may be of most concern: First, although my experiments were conducted on a small scale, it seems likely that the total abundance of native kelp in the San Juan Islands has been reduced by $S$. muticum. Since a wide variety of taxa, including even marine mammals and birds, utilize these shallow subtidal kelp communities, the consequences of this invasion may extend well beyond the benthic organisms that were the focus of this study. Second, the avoidance by green urchins of areas with dense $S$. muticum has important potential indirect effects for kelp communities. Urchins are an important disturbance agent because they clear patches of rock, thereby resetting the successional sequence of the community (Vadas 1968, Duggins 1980). As a consequence, algal diversity is enhanced by the creation of a mosaic of patches that differ in their successional stages (Vadas 1968, Duggins 1980). The absence of green urchins could ultimately cause a decline in macroalgal diversity in shallow, subtidal kelp communities. Furthermore, by concentrating their grazing in areas outside $S$. muticum populations, green urchins may facilitate the spread of this invader, which has higher recruitment in areas that have been experimentally denuded of algae (Britton-Simmons 2003).

The response of green urchins to the presence of Sargassum muticum suggests that this generalist herbivore is presently unlikely to slow the rate of $S$. muticum's spread (Figs. $6 \& 11$ ). The food preferences of green urchins could change over time so that $S$. muticum becomes a more preferred food resource. Moreover, natural selection could eventually favor such a shift, especially if $S$. muticum continues to increase in abundance and displace palatable native kelp species. However, S. muticum's wiry morphology and positive buoyancy may make it largely inaccessible to green urchins and thereby preclude an evolutionary shift in feeding preferences.

My removal experiments were conducted at sites where the abundance of Sargassum muticum is at the upper end of its distribution of densities. If the effect of $S$. muticum on light is proportional to its abundance, then I would expect its effect on native species at any particular site to also be proportional to abundance. 
Nevertheless, a more complex relationship is possible. For example, other studies have shown that the sign of an interaction between exotic and native species can change as their relative densities change (Reush \& Williams 1998). Thus, it may be necessary to evaluate the effects of $S$. muticum at various densities in order to understand more completely how it interacts with native species. At low densities it may have a relatively small effect on light, although even this small effect may be sufficient to alter the competitive outcome of interspecific interactions among native kelps without reducing overall kelp abundance.

This study illustrates that an introduced alga can have important effects on native communities. These results, in combination with other studies that have also demonstrated strong effects of non-indigenous algae species (Verlaque 1994b, Villele \& Verlaque 1995, Walker \& Kendrick 1998, Levin et al. 2002) highlight the importance of future research into the spread and impact of introduced algae. Because of their worldwide distribution and capacity to alter native communities, non-indigenous algae are potentially important agents of global ecological change.

Acknowledgements. None of this work would have been possible without the many individuals who volunteered their time to dive with me on this project. I am especially grateful to J. Kido, E. Iyengar, B. Pister, L. Self, and C. Catton for being my 'buddies'. For thoughtful discussions which improved the quality of this work I thank T. Wootton, C. Pfister, M. Leibold, J. Bergelson, G. Dwyer, S. Williams, D. Duggins, T. Klinger, J. Kido, S. Hall, K. Polivka, P. Geddes, S. Harrell and B. Pister. J. Bergelson, C. Pfister, J. Byers, M. Wilson, K. Abbott, T. Wootton, C. Peterson, and 2 anonymous reviewers helped me transform early versions of this manuscript into its present form. T. Wootton gave guidance and encouragement throughout this project. The staff of Friday Harbor Laboratories provided logistical support including boats, dive facilities and laboratory space, and for that I am thankful. This work was funded by grants to K.B.S. from The Packard Foundation and The University of Chicago's Hinds Fund, and grants to T. Wootton from The Marine Ecosystem Health Program and The Mellon Foundation. K.B.S. was supported by a Department of Education GAANN fellowship during the course of this study.

\section{LITERATURE CITED}

Ambrose RF, Nelson BV (1982) Inhibition of giant kelp recruitment by an introduced brown alga. Bot Mar 25:265-267

Bernstein BB, Jung N (1979) Selective pressures and coevolution in a kelp canopy community in southern California. Ecol Monogr 49:335-355

Britton-Simmons KH (2003) Establishment, spread, and impact of the introduced Japanese seaweed, Sargassum muticum, in the San Juan Islands, WA. PhD thesis, The University of Chicago, Chicago

Burnham KP, Anderson DR (1998) Model selection and inference: a practical information-theoretic approach. Springer Verlag, New York
Cohen BF, McArthur MA, Parry GD (2001) Exotic marine pests in the Port of Melbourne, Victoria. MAFRI Rep 25: $1-96$

DeWreede RE (1983) Sargassum muticum (Fucales, Phaeophyta): regrowth and interaction with Rhodomela larix (Ceramiales, Rhodophyta). Phycologia 22:153-160

DeWreede RD (1996) The impact of seaweed introductions on biodiversity. Global Biodiv 6(3):2-9

DeWreede RE, Vandermeulen R (1988) Lithothrix aspergillum (Rhodophyta): regrowth and interaction with Sargassum muticum (Phaeophyta) and Neorhodomela larix (Rhodophyta). Phycologia 27:469-476

Deysher L, Norton R (1982) Dispersal and colonization in Sargassum muticum (Yendo) Fensholt. J Exp Mar Biol Ecol $56: 179-185$

Duggins DO (1980) Kelp beds and sea otters: an experimental approach. Ecology 61(3):447-453

Duggins DO, Simenstad CA, Estes JA (1989) Magnification of secondary production by kelp detritus in coastal marine ecosystems. Science 245:170-173

Ebeling AW, Laur DR, Rowley RJ (1985) Severe storm disturbances and reversal of community structure in a southern California kelp forest. Mar Biol 84:287-294

Eckman JE, Duggins DO, Sewell AT (1989) Ecology of understory kelp environments. I. Effects of kelps on flow and particle transport on the bottom. J Exp Mar Biol Ecol 129: 173-187

Faul F, Erdfelder E (1992) GPOWER: a priori, post-hoc, and compromise power analyses for MS-DOS (Computer program). Bonn University, Department of Psychology, Bonn

Forrest BM, Brown SN, Taylor MD, Hurd CL, Hay CH (2000) The role of natural dispersal mechanisms in the spread of Undaria pinnatifida (Laminariales, Phaeophyceae). Phycologia 39:547-553

Fredriksen S, Sjotun F, Lein T, Rueness J (1995) Spore dispersal in Laminaria hyperborea (Laminariales, Phaeophyceae). Sarsia 80:47-53

Gardner WD (1980) Sediment trap dynamics and calibration: a laboratory evaluation. J Mar Res 38:41-52

Giver KJ (1999) Effects of the invasive seaweed Sargassum muticum on native marine communities in northern Puget Sound, Washington. MS thesis, Western Washington University, Bellingham

Hammerstrom K, Dethier MN, Duggins DO (1998) Rapid phlorotannin induction and relaxation in five Washington kelps. Mar Ecol Prog Ser 165:293-305

Hayduk LA (1987) Structural equation modeling with LISREL. Johns Hopkins University Press, Baltimore

Jones LC (1971) Studies on selected small herbivorous invertebrates inhabiting Macrocystis canopies and holdfasts in southern California kelp beds. Nova Hedwigia 32: 343-367

Juerg B (1996) Towards a new generation of sediment traps and a better measurement/understanding of settling particle flux in lakes and oceans: a hydrodynamical protocol. Aquat Sci 58:283-296

Larson BR, Vadas RL, Keser M (1980) Feeding and nutritional ecology of the sea urchin Stronglyocentrotus droebachiensis in Maine, USA. Mar Biol 59:49-62

Levin PS, Coyer JA, Petrik R, Good TP (2002) Communitywide effects of non-indigenous species on temperate rocky reefs. Ecology 83:3182-3193

Lobban CS, Harrison PJ (1994) Seaweed ecology and physiology. Cambridge University Press, New York

Lüning K (1981) Light. In: Lobban CS, Wynne MJ (eds) The biology of seaweeds. University of California Press, Berkeley, p 340-342 
Norton TA (1977) The growth and development of Sargassum muticum (Yendo) Fensholt. J Exp Mar Biol Ecol 26:41-53

Peterson CH, Renaud PE (1989) Analysis of feeding preference experiments. Oecologia 80:82-86

Pfister CA, Hay ME (1988) Associational plant refuges: convergent patterns in marine and terrestrial communities result from differing mechanisms. Oecologia 77:118-129

Pfister CA, Van Alstyne KL (2003) An experimental assessment of the effects of nutrient enhancement on the intertidal kelp Hedophyllum sessile (Laminariales, Phaeophyceae). J Phycol 39:285-290

Reed DC, Laur DR, Ebeling AW (1988) Variation in algal dispersal and recruitment: the importance of episodic events. Ecol Monogr 58:321-335

Reush TBH, Williams SL (1998) Variable responses of native eelgrass Zostera marina to a non-indigenous bivalve Musculista senhousia. Oecologia 113:428-441

Rueness J (1989) Sargassum muticum and other introduced Japanese macroalgae: biological pollution of European coasts. Mar Pollut Bull 20(4):173-176

Scagel RF (1956) Introduction of a Japanese alga, Sargassum muticum, into the Northeast Pacific. Fish Res Pap St Wash $1: 1-10$

Setzer B, Link C (1971) The wanderings of Sargassum muticum and other relations. Stomatopod 2:5-6

Shipley B (2000) Cause and correlation in biology (a user's guide to path analysis, structural equations and causal inference). Cambridge University Press, Cambridge

Sokal RR, Rohlf FJ (1995) Biometry: the principle and practice of statistics in biological research, 3rd edn. WH Freeman, New York

Staehr PA, Pedersen MF, Thomsen MS, Wernberg T, KrauseJensen D (2000) The invasion of Sargassum muticum in Limfjorden (Denmark) and its possible impact on the indigenous macroalgal community. Mar Ecol Prog Ser 207:79-88

UNESCO (1994) Protocols for the Joint Global Ocean Flux

Editorial responsibility: Charles Peterson (Contributing Editor), Morehead City, North Carolina, USA
Study (JGOFS) core measurements. Intergovernmental Oceanographic Commission (IOC), manual and guides No 29. Paris, France

Vadas RL (1968) The ecology of Agarum and the kelp bed community. PhD thesis, University of Washington, Seattle

Vadas RL (1977) Preferential feeding: an optimization strategy in sea urchins. Ecol Monogr 47:337-371

Verlaque M (1994a) Checklist of introduced plants in the Mediterranean: origins and impact on the environment and human activities. Oceanol Acta 17:1-23

Verlaque M (1994b) Mediterranean algal communities are changing in the face of the invasive alga Caulerpa taxifolia (Vahl) C. Agardh. Oceanol Acta 17:659-672

Viejo RM (1997) The effects of colonization by Sargassum muticum on tidepool macroalgal assemblages. J Mar Biol Assoc UK 77:325-340

Villele X de, Verlaque M (1995) Changes and degradation in a Posidonia oceanica bed invaded by the introduced tropical alga Caulerpa taxifolia in the north western Mediterranean. Bot Mar 38:1-9

Walker DI, Kendrick GA (1998) Threats to macroalgal diversity: marine habitat destruction and fragmentation, pollution and introduced species. Bot Mar 41:105-112

Wilson M (2001) Is Sargassum muticum a benign invader of tidepools on the Pacific coast of North America? MS thesis, California State University Monterey Bay, Seaside

Wootton JT (1991) Direct and indirect effects of nutrient on intertidal community structure: variable consequences of seabird guano. J Exp Mar Biol Ecol 151:139-153

Wootton JT (1994) Predicting direct and indirect effects: an integrated approach using experiments and path analysis. Ecology 75:151-165

Yendo K (1907) The Fucaceae of Japan. J Coll Sci Imp Univ Tokyo 21(12):1-174

Zar JH (1999) Biostatistical analysis, 4th edn. Prentice Hall, Upper Saddle River, NJ

Submitted: February 3, 2003; Accepted: February 3, 2004

Proofs received from author(s): August 9, 2004 